\begin{tabular}{|l|l|l||}
\hline \multicolumn{2}{|c|}{ PublisherInfo } \\
\hline \hline PublisherName & $:$ & BioMed Central \\
\hline \hline PublisherLocation & $:$ & London \\
\hline \hline PublisherImprintName & $:$ & BioMed Central \\
\hline \hline
\end{tabular}

\title{
A database of proteins that are known to interact
}

\begin{tabular}{||l|l|l||}
\hline \multicolumn{2}{|c||}{ ArticleInfo } \\
\hline \hline ArticleID & $:$ & 3594 \\
\hline \hline ArticleDOI & $:$ & $10.1186 /$ gb-2000-1-1-reports220 \\
\hline \hline ArticleCitationID & $:$ & reports220 \\
\hline \hline ArticleSequenceNumber & $:$ & 85 \\
\hline \hline ArticleCategory & $:$ & Web report \\
\hline \hline ArticleFirstPage & $:$ & 1 \\
\hline \hline ArticleLastPage & $:$ & 3 \\
\hline \hline & & RegistrationDate : 1999-11-18 \\
ArticleHistory & $:$ & Received \\
\hline ArticleCopyright & $:$ & BioMed Central Ltd2000 \\
\hline \hline ArticleGrants & $:$ & \\
\hline \hline ArticleContext & $:$ & 130591111 \\
\hline \hline
\end{tabular}




\section{Iain Gilfillan}

\section{Abstract}

DIP is intended to help those studying protein-protein interactions, signaling pathways, multiple interactions and complex systems.

\section{Content}

The database of interacting proteins (DIP) is intended to help those studying protein-protein interactions, signaling pathways, multiple interactions and complex systems. It contains information on pairs of interacting proteins, including the Protein information resource (PIR) unique ID for each protein, information about the regions involved in the interaction for each pair, as well as the dissociation constant and the experimental methods used to study the interaction. The database is updated via web submissions, which means that anyone can add an interacting pair of proteins. Searches will also identify homologous proteins and external links to the Protein information resource database and Protein data bank (PDB) entries, where available.

\section{Navigation}

The size of the site means that one cannot get too lost, but it would be nice if every page had a link back to the homepage. Searches can be carried out on the whole database or on specific fields, such as name, species or keyword.

\section{Reporter's comments}

\section{Timeliness}

The site was last updated 21 October 1999. 


\section{Wish list}

The pages would benefit from better annotation, and the search results could be better labeled and presented, as the significance of the information returned is not always immediately apparent.

\section{Related websites}

More information on signaling proteins can be found at the Signaling pathway database and the Cell signaling networks database.

\section{Table of links}

Database of interacting proteins (DIP)

Protein information resource

Protein data bank

Signaling pathway database

Cell signaling networks database

\section{References}

1. Database of interacting proteins (DIP). 